\title{
ARTICLE
}

\section{Nephroprotective efficacy of Asparagus racemosus root extract on acetaminophen-induced renal injury in rats}

\author{
Suchismita Roy', Shrabani Pradhan', Shreya Mandal'2, Koushik Das², Dilip Kumar Nandi²* \\ ${ }^{1}$ Department of Biological Sciences, Midnapore City College, Kuturia, Bhadutala, Midnapore- 721129, West Bengal, \\ India \\ ${ }^{2}$ Research Unit, Developed by Department of Nutrition, Physiology \& Microbiology, Raja N. L. Khan Women's \\ College, Midnapore, West Bengal, India
}

\begin{abstract}
Acetaminophen-induced renal necrosis and insufficiency occurs in patients with acetaminophen overdose. Renal failure is rapidly assuming epidemic proportions globally. In absence of reliable and effective nephroprotective drugs, strategies towards exploring alternative therapies for treatment of kidney diseases are essential. Asparagus racemosus is a medicinal plant used for treatment of various ailments. This research was undertaken to investigate the protective effect of ethanol fraction of $A$. racemosus roots extract in acetaminophen-induced uraemia and renal failure in rats. Rats were co-administered with acetaminophen injection and oral administration of $A$. racemosus roots extract in an attempt of protection against renal failure. Uremic biomarkers significantly decreased, and elevated levels of antioxidant enzymes were found, in the animals treated with ethanol fraction of $A$. racemosus when compared with acetaminophen treated uremic animals. Also, histology of kidneys showed control like structure in animals treated with this extract but severe damage in the uremic animals. HPLC analysis of the ethanol fraction of $A$. racemosus roots extract revealed eight compounds out of which one had a retention time near to the quercetin standard. It may be concluded that this extract of $A$. racemosus has therapeutically useful nephroprotective potential.

Acta Biol Szeged 62(1):17-23 (2018)
\end{abstract}

\section{KEY WORDS}

acetaminophen nephroprotection renal failure

\section{ARTICLE INFORMATION}

Submitted

9 February 2018.

Accepted

21 May 2018

*Corresponding author

E-mail: dilipnandi2004@yahoo.co.in

\section{Introduction}

Acetaminophen (N-acetyl-p-aminophenol; APAP), also known as paracetamol, is one of the most effective overthe-counter analgesic-antipyretic chemotherapeutic agents belonging to the para-aminophenol class of the non-steroidal anti-inflammatory drugs (NSAIDs) (Hardman et al. 2001) and is considered safe at therapeutic dosages. Acute and chronic high doses of APAP are known to cause hepatic necrosis in both animals and humans (O'Grady 1997), but impairment of renal function by acetaminophen as the main untoward effect is also becoming increasingly reported (McLaughlin et al. 1998; Fored et al. 2001).

Different research work done on the anti-uremic and nephroprotective phytochemicals from different plant extracts such as methanolic bark extract of Terminalia arjuna (Das et al. 2010a), methanolic root extract of Withania somnifera (Das et al. 2010b) which had been effective to reduce uremic toxins in experimentally induced renal failure in rats. Other research work, undertaken on nutraceuticals like alpha lipoic acid (Pradhan et al. 2013) and on probiotic therapy (Mandal et al. 2013c) as an alternative; both the work was shown to have excellent nephroprotective activity against acetaminophen-induced renal failure in male rats.

In Indian system of medicine, Asparagus racemosus (Liliaceae) is an important medicinal plant having a wide range of biological activities (Goyal et al. 2003). The therapeutic components present in the root of $A$. racemosus are phytosterols, saponins, polyphenols, flavonoids and ascorbic acid (Visavadiya and Narsimhacharya 2005). The aim of the present study was to evaluate the protective effect of the ethanol fraction of A. racemosus roots (AR) against acetaminophen-induced nephrotoxicity in male albino rats by evaluating biochemical and histological alterations. HPLC analysis of phytochemicals to search out most active compounds in this plant was also performed. 
Roy et al.

Table 1. Grouping of animals with the treatment

\begin{tabular}{lll}
\hline Groups & Number of rats & Treatments \\
\hline Group I & 6 rats & $\begin{array}{l}\text { Served as untreated control and was provided normal food and water. } \\
\text { Eroup II }\end{array}$ \\
Group III & 6 rats & $\begin{array}{l}\text { gavage for } 10 \text { days. One } g \text { of ethanol fraction of AR was dissolved in } 1 \mathrm{ml} \text { of deionized water. } \\
\text { Uremic animals were treated with intraperitoneal APAP injection at } 500 \mathrm{mg} / \mathrm{kg} \text { body weight/day once } \\
\text { in every day for } 10 \text { consecutive days. One } \mathrm{g} \text { of APAP was dissolved in } 1 \mathrm{ml} \text { of deionized water. } \\
\text { Orally feeding with ethanol fraction of AR at the dose of } 500 \mathrm{mg} / \mathrm{kg} \text { body weight/day with co admin- } \\
\text { istration of intraperitoneal APAP injection at } 500 \mathrm{mg} / \mathrm{kg} \text { body weight/day once in every day for } 10 \\
\text { consecutive days. }\end{array}$ \\
\hline
\end{tabular}

\section{Materials and methods}

\section{Drug and chemicals}

Acetaminophen (paracetamol, $\mathrm{N}$-acetyl $\mathrm{p}$-aminophenol; APAP) was purchased from AshChemie India (Thane, India). It was administered intraperitoneally with saline. All other chemicals and kits were obtained from Merck (Mumbai, India) and HiMedia Laboratories (Mumbai, India).

\section{Plant materials}

The root of A. racemosus was collected from Gopali, Indian Institute of Technology, Kharagpur (Paschim Medinipur district, West Bengal). Plant material was identified by taxonomist at the Department of Botany, Raja N. L. Khan Women's College, Midnapore. The voucher specimens were deposited at the Department of Botany (Raja N. L. Khan Women's College).

\section{Animal care and selection}

The study was conducted on 24 healthy adult male albino rats of Wistar strain (Ghosh Animal, Kolkata 54, India) having a body weight of $90 \pm 10 \mathrm{~g}$. They were acclimatized to laboratory conditions for two weeks prior to experimentation. The animals were grouped and housed in polyacrylic cages $(38 \times 23 \times 10 \mathrm{~cm})$ three rats/cage in a temperature-controlled room $\left(22 \pm 2{ }^{\circ} \mathrm{C}\right)$ with $12-12 \mathrm{~h}$ dark-light cycles (8.00-20.00 h light, $20.00-8.00 \mathrm{~h}$ dark) at a humidity of $50 \pm 10 \%$. They were provided with standard food and water ad libitum. Animal care (NIH 1985) was provided according to the guiding principle for the care and use of animals (Olfert et al. 1993). This experiment was approved by our Institutional Animal Ethical Committee according to the CPCSEA guidelines (CPCSEA Registration No- 1905/PO/Re/S/2016/CPCSEA).

\section{Preparation of ethanol fraction of $A R$}

Roots of $A$. racemosus were washed and cut into small pieces then shade dried and crushed in an electrical grinder. A total of $100 \mathrm{~g}$ powdered root material was washed in 400 $\mathrm{ml}$ of hexane for $24 \mathrm{~h}$ to remove the greasy non-polar components. The hexane was discarded, and residue was dissolved in hydromethanol (methanol and water mixture 4:6) for $2 \mathrm{~h}$ in a Soxhlet apparatus. Then the extract was filtered through Whatman No. 1 filter paper and the filtrate was evaporated in a rotary vacuum evaporator. Of this hydromethanol extract residue, $25 \mathrm{~g}$ was dissolved in $500 \mathrm{ml}$ ethyl acetate for $2 \mathrm{~h}$ in a Soxhlet apparatus. The extract was filtered, and the resulting filtrate was dried in the air. The ethyl acetate extract was then dissolved in $250 \mathrm{ml}$ ethanol for $2 \mathrm{~h}$ in a Soxhlet apparatus. Then it was filtered, and the resulting filtrate was dried under reduced pressure at $40^{\circ} \mathrm{C}$ on a rotary evaporator (Das et al. 2010b; Roy et al. 2014b; Roy et al. 2014a). The fraction was named as ethanol fraction of $A$. racemosus (AR) and it was stored in refrigerator for further study.

\section{Grouping of animals}

Twenty-four rats were divided into four groups. The dose of acetaminophen and AR was established in our laboratory according to OECD guidelines (Roy et al. 2015; Roy et al. 2014a), by acute and main toxicity study. The details of groups with the 10-days treatment are given in Table 1.

\section{Animal scarification, plasma and organ collection}

This experimental design was continued for 10 days. On the $11^{\text {th }}$ day, the animals were sacrificed by exsanguinations method and using chloroform anaesthesia. Blood was collected from the aorta for biochemical and haematological analysis, after which the liver was collected for liver glutathione content and histopathological analysis. Blood was centrifuged at $10000 \mathrm{~g}$ for $20 \mathrm{~min}$ at $4^{\circ} \mathrm{C}$ and then plasma was collected.

\section{Measurement of biochemical parameters}

Plasma urea and creatinine level were measured by standard kit method (Pradhan et al. 2013; Burtis and Ashwood 1999). Quantification of plasma sodium and potassium was done by standard kit methods using electrolyte analyser (Systronics, India) by using plasma samples (Sunderman 1959; Roy et al. 2013). Activity of the antioxidant enzymes catalase (CAT; Pradhan et al. 2013; Beers and Sizer 1952), 
Table 2. Effect of ethanol fraction of $A$. racemosus on body weight in rats with acetaminophen-induced renal failure. Data were expressed as mean $\pm \mathrm{SE}$ $(n=6)$ and data with different superscripts $(a, b$ and $c)$ in a specific vertical column differ from each other significantly $(p<0.05)$.

\begin{tabular}{llll}
\hline Groups & Initial body weight $(\mathrm{g})$ & Final body weight $(\mathrm{g})$ & Increase or decrease in body weight $(\mathrm{g})$ \\
\hline I & $104.2 \pm 2.5^{\mathrm{a}}$ & $120.3 \pm 5.3^{\mathrm{a}}$ & 16.1 \\
II & $106.4 \pm 3.8^{\mathrm{a}}$ & $126.3 \pm 4.7^{\mathrm{c}}$ & 19.9 \\
III & $105.6 \pm 3.6^{\mathrm{a}}$ & $109.2 \pm 3.2^{\mathrm{b}}$ & 3.6 \\
IV & $106.7 \pm 3.1^{\mathrm{a}}$ & $122.5 \pm 6.2^{\mathrm{a}}$ & 15.8 \\
\hline
\end{tabular}

and superoxide dismutase (SOD; Marklund and Marklund 1947; Roy et al. 2015), and GSH level (Elkarib 2014) were measured spectrophotometrically from plasma and kidney samples. SOD and CAT are the most important enzymes involved in ameliorating the effects of oxygen metabolism (Linares et al. 2006). The oxidative stress marker MDA was determined by UV-VIS spectrophotometer (Systronics, India) as described in Roy et al. (2015) and Ohkawa et al. (1976). Histology of kidney tissue was performed by standard method (Roy et al. 2015; Mukherjee 2010).

Table 3. Effect of ethanol fraction of A. racemosus on plasma and kidney catalase in rats with acetaminophen-induced renal failure. Data were expressed as mean $\pm \operatorname{SE}(n=6)$ and data with different superscripts ( $a$ and $b)$ in a specific vertical column differ from each other significantly $(p<0.05)$.

\begin{tabular}{lll}
\hline Groups & $\begin{array}{l}\text { Plasma catalase } \\
\text { (mmol of } \mathrm{H}_{2} \mathrm{O}_{2} \\
\text { consumption/dl } \\
\text { of plasma/min) }\end{array}$ & $\begin{array}{l}\text { Kidney catalase } \\
\text { (mmol of } \mathrm{H}_{2} \mathrm{O}_{2} \\
\text { consumption } / \mathrm{mg} \\
\text { of tissue/min) }\end{array}$ \\
\hline I & $0.92 \pm 0.08^{\mathrm{a}}$ & $0.97 \pm 0.05^{\mathrm{a}}$ \\
II & $0.94 \pm 0.17^{\mathrm{a}}$ & $0.96 \pm 0.07^{\mathrm{a}}$ \\
III & $0.13 \pm 0.03^{\mathrm{b}}$ & $0.26 \pm 0.04^{\mathrm{b}}$ \\
IV & $0.88 \pm 0.06^{\mathrm{a}}$ & $0.92 \pm 0.07^{\mathrm{a}}$ \\
\hline
\end{tabular}

\section{Statistical analysis}

Analysis of variance (ANOVA) followed by a multiple two-tail t-test with Bonferroni modification was used for statistical analysis of the collected data.

\section{HPLC analysis}

HPLC analysis of AR was carried out on a Thermo Fisher
HPLC system equipped with an ODS-2 $250 \times$ 4.6, $5 \mu \mathrm{m}$ (Thermo Scientific, UK) reverse phase chromatographic column using UV detector at $254 \mathrm{~nm}$. For the separation, $4.6 \mathrm{mM}, \mathrm{pH} 7.2$ phosphate buffer (A) and acetonitrile (B) were applied in the ratio of 1:1. The flow rate was $1.5 \mathrm{ml} / \mathrm{min}$ at $37^{\circ} \mathrm{C}$ and the injection volume was $20 \mu \mathrm{l}$. Concentration of test solution used for this study was $50 \mathrm{mg}$ dry weight $/ \mathrm{ml}$ dissolved in methanol. The run time was $45 \mathrm{~min}$ and quercetin was used as a standard for HPLC analysis.

\section{Results}

\section{Body weight (BW)}

BW was measured prior to experiment and final BW was taken before animal sacrification. Due to acetaminophen-induced uraemia and oxidative stress, there was a decreased rate of body weight gain in uremic group in comparison to Group I, II and IV. Also, in Group IV, the animals' BW was significantly $(\mathrm{P}<0.05)$ increased when compared with Group III animals and it was similar to control group of animals as shown in Table 2.

\section{Antioxidants and lipid peroxidation}

Activity of CAT and SOD, as well as GSH levels, were significantly $(\mathrm{P}<0.05)$ decreased in the acetaminopheninduced uremic Group III animals comparing control group of animals (Table 3 and 4). But on co administration of AR at $500 \mathrm{mg} / \mathrm{kg} \mathrm{BW/day} \mathrm{for} 10$ days to the Group IV animals these antioxidant enzyme levels shifted towards control group of animals and increased significantly ( $\mathrm{P}$ $<0.05$ ) when compared with Group III.

Table 4. Effect of ethanol fraction of $A$. racemosus on SOD and GSH level in rats with acetaminophen-induced renal failure. Data were expressed as mean $\pm S E(n=6)$ and data with different superscripts $(a, b$ and $c)$ in a specific vertical column differ from each other significantly $(p<0.05)$.

\begin{tabular}{|c|c|c|c|}
\hline Groups & $\begin{array}{l}\text { Plasma SOD } \\
\text { (mmol of } \mathrm{H}_{2} \mathrm{O}_{2} \text { consumption/dl of plasma/min) }\end{array}$ & $\begin{array}{l}\text { Kidney SOD } \\
\text { (mmol of } \mathrm{H}_{2} \mathrm{O}_{2} \text { consumption/mg of tissue/min) }\end{array}$ & $\begin{array}{l}\text { Kidney GSH } \\
\text { ( } \mu \mathrm{mol} / \mathrm{g} \text { of tissue) }\end{array}$ \\
\hline I & $0.95 \pm 0.06^{a}$ & $1.31 \pm 0.08^{a}$ & $19.53 \pm 2.43^{a}$ \\
\hline II & $0.98 \pm 0.04^{a}$ & $1.38 \pm 0.08^{a}$ & $20.03 \pm 3.17^{a}$ \\
\hline III & $0.48 \pm 0.05^{b}$ & $0.55 \pm 0.08^{b}$ & $5.44 \pm 0.83^{b}$ \\
\hline IV & $0.92 \pm 0.07^{a}$ & $1.32 \pm 0.07^{a}$ & $13.66 \pm 1.58^{c}$ \\
\hline
\end{tabular}


Table 5. Effect of ethanol fraction of $A$. racemosus on plasma and kidney MDA level in rats with acetaminophen-induced renal failure. Data were expressed as mean $\pm S E(n=6)$ and data with different superscripts ( $a$ and b) in a specific vertical column differ from each other significantly $(p<0.05)$.

\begin{tabular}{lll}
\hline Groups & $\begin{array}{l}\text { Plasma MDA } \\
\text { (nmol/dl of plasma) }\end{array}$ & $\begin{array}{l}\text { Kidney MDA } \\
\text { (nmol/mg of tissue) }\end{array}$ \\
\hline I & $20.9 \pm 6.27^{\mathrm{a}}$ & $26.9 \pm 3.5^{\mathrm{a}}$ \\
II & $23.5 \pm 8.5^{\mathrm{b}}$ & $26.7 \pm 2.03^{\mathrm{b}}$ \\
III & $49.02 \pm 5.2^{\mathrm{b}}$ & $63.4 \pm 1.9^{\mathrm{a}}$ \\
IV & $23.8 \pm 3.5^{\mathrm{a}}$ & $42.1 \pm 0.32^{\mathrm{a}}$ \\
\hline
\end{tabular}

Plasma and kidney MDA levels were increased significantly $(\mathrm{P}<0.05)$ in Group III animals in comparison to Group I, II and IV (Table 5). On oral administration of AR to Group IV animals, the levels of MDA decreased significantly $(\mathrm{P}<0.05)$ in comparison to Group III (Table 5 ) and the values were very near to the control. So, the ethanol fraction of AR significantly resettled the MDA value near to the control and prevented lipid peroxidation.

\section{Renal function effects}

There was a significantly $(\mathrm{P}<0.05)$ higher plasma sodium, and lower plasma potassium, level in Group III animals in comparison to other groups (Table 6), indicating that electrolyte balance was hampered due to nephrotoxicity. In Group IV, co administered with AR and acetaminophen for 10 days, electrolyte imbalance was prevented.

There was also a significant $(\mathrm{P}<0.05)$ increase in

Table 6. Effect of ethanol fraction of $A$. racemosus on plasma sodium and potassium level in rats with acetaminophen-induced renal failure. Data were expressed as mean $\pm \operatorname{SE}(n=6)$. Data with different superscripts ( $a$ and $b$ ) in a column differ from each other significantly $(p<0.05)$.

\begin{tabular}{lll}
\hline Groups & $\begin{array}{l}\text { Plasma sodium } \\
(\mathrm{mmol} / \mathrm{l})\end{array}$ & $\begin{array}{l}\text { Plasma potassium } \\
(\mathrm{mmol} / \mathrm{l})\end{array}$ \\
\hline I & $132.3 \pm 3.5^{\mathrm{a}}$ & $4.76 \pm 0.42^{\mathrm{a}}$ \\
II & $134.2 \pm 4.22^{\mathrm{a}}$ & $4.87 \pm 0.58^{\mathrm{a}}$ \\
III & $182.72 \pm 2.53^{\mathrm{b}}$ & $2.67 \pm 0.37^{\mathrm{b}}$ \\
IV & $138.5 \pm 6.3^{\mathrm{a}}$ & $4.68 \pm 0.47^{\mathrm{a}}$ \\
\hline
\end{tabular}

Table 7. Effect of ethanol fraction of $A$. racemosus on plasma urea and creatinine level in rats with acetaminophen-induced renal failure. Data were expressed as mean $\pm S E(n=6)$. Data with different superscripts ( $a$ and $b)$ in a column differ from each other significantly $(p<0.05)$.

\begin{tabular}{lll}
\hline Groups & $\begin{array}{l}\text { Plasma urea } \\
(\mathrm{mg} / \mathrm{dl})\end{array}$ & $\begin{array}{l}\text { Plasma creatinine } \\
(\mathrm{mg} / \mathrm{dl})\end{array}$ \\
\hline I & $22.5 \pm 2.27^{\mathrm{a}}$ & $0.36 \pm 0.05^{\mathrm{a}}$ \\
II & $20.08 \pm 3.6^{\mathrm{b}}$ & $0.37 \pm 0.03^{\mathrm{b}}$ \\
III & $66.2 \pm 4.2^{\mathrm{b}}$ & $1.27 \pm 0.09^{\mathrm{a}}$ \\
IV & $34.8 \pm 2.5^{\mathrm{a}}$ & $0.39 \pm 0.02^{\mathrm{a}}$ \\
\hline
\end{tabular}
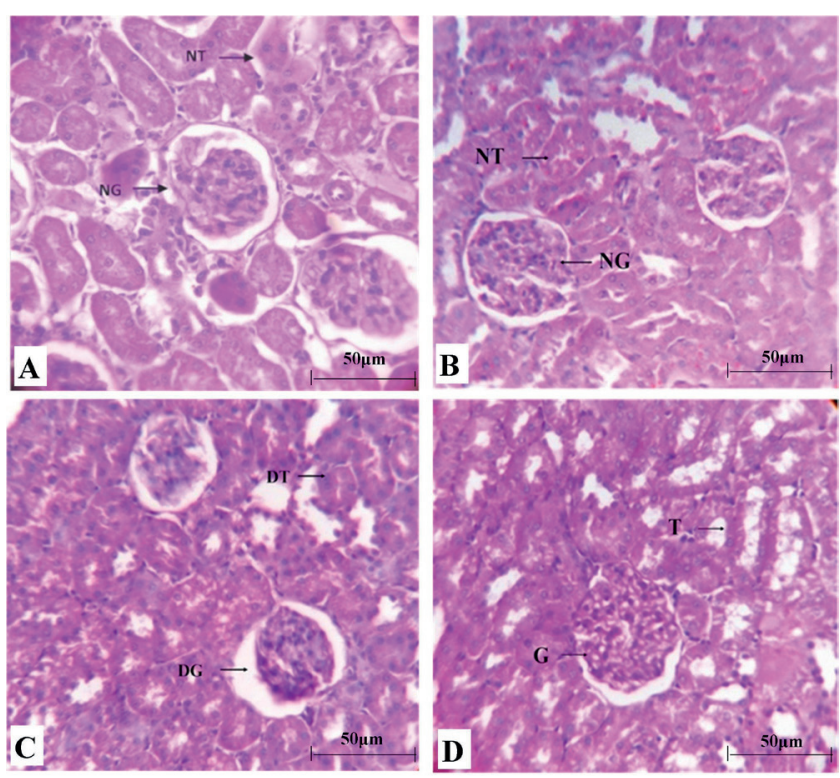

Figure 1. Histology of kidney tissues stained with hematoxylin and eosin magnified using a $40 \mathrm{X}$ objective. Figure $1 \mathrm{~A}$ showing normal histology of kidney of control group of rats with normal glomerulus (NG) and renal tubules (NT) are well organized in histoarchitecture. Figure 1B showing normal histology of kidney of AR treated control group of rats with normal glomerulus (NG) and renal tubules (NT) are well organized in histoarchitecture. Figure $1 \mathrm{C}$ showing severe disorganization of rat kidney after acetaminophen injection of $500 \mathrm{mg} / \mathrm{kg}$ body weight to Group II rats, where damaged glomerulus (DG) and dilated renal tubules (DT) are seen. Figure 1D showing acetaminophen induced nephrotoxic rat kidney (500 mg/kg body weight) with treatment by AR $(500 \mathrm{mg} / \mathrm{kg}$ ) for 10 days to group IV rats showing control like histology with normal glomerulus $(\mathrm{G})$ and renal tubule $(\mathrm{T})$.

the plasma urea and creatinine concentrations in the Group III. In Group IV, urea and creatinine level was significantly $(\mathrm{P}<0.05)$ decreased and was very close to the controls (Table 7). Administration of AR apparently exerts maximum antioxidative and antiuremic effects on APAP-induced uremic and oxidative damage in rats.

\section{Histology}

The histological pattern of the kidney in control and AR-treated rats showed normal tubular brush borders and intact glomeruli and Bowman's capsule (Fig. 1A, B). APAP-induced uremic Group III animals showed kidney tissues with severe tubular necrosis and degeneration in the renal tissues (Fig. 1C): dilation in tubules (DT), damaged glomeruli with a mild degree of swelling, necrosis and degranulation were present. Coadministration of AR for 10 days in Group IV ameliorated the toxic manifestations of acetaminophen in the kidney, normal glomerulus $(\mathrm{G})$ with organized normal tubules (T) were seen (Fig. 1D).

\section{HPLC analysis}

Analysis of AR revealed two major and six minor peaks in the HPLC chromatogram; the two major peaks were 


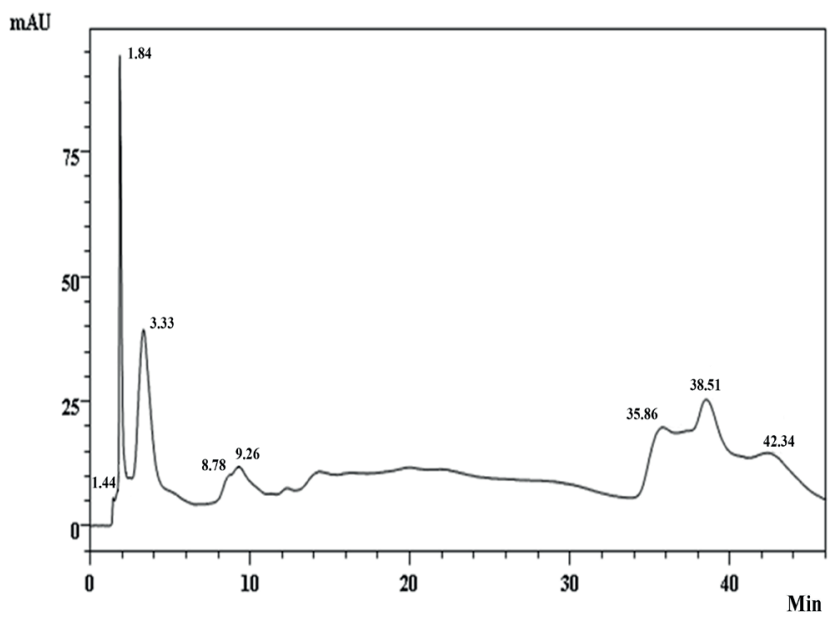

Figure 2. HPLC chromatogram of ethanol fraction of AR showing eight separate peaks.

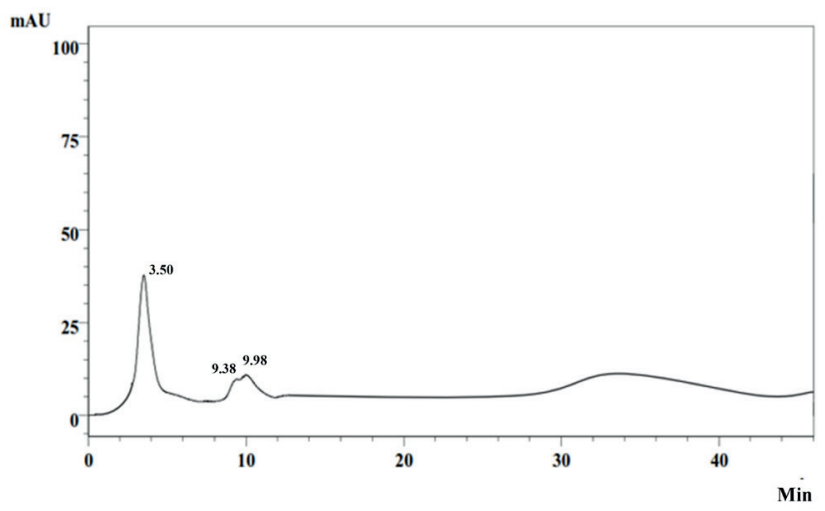

Figure 3. HPLC chromatogram of standard quercetin with one distinct peak and other minor peaks.

found at retention times of 1.849 and 3.334, respectively (Fig. 2). The quercetin standard had a HPLC chromatogram with three peaks (Fig. 3). The major compound of AR had a similar retention time (3.334) as found for the major compound of quercetin standard (3.507).

\section{Discussion}

Body weight gain decreased in uremic animals by repeated dose of acetaminophen due to oxidative stress, but co administration of ethanol fraction of AR brought the body weight back towards control.

Generation of reactive oxygen species has been proposed as a mechanism by which different chemicals can induce nephrotoxicity (Somani et al. 2000). During kidney injury, superoxide radicals were generated in body and modulate SOD and CAT, resulting in the loss of activity and accumulation of superoxide radical, which damages kidney. Several pathways are known for acetaminophen metabolism. By sulfation and glucoronidation $90 \%$ of APAP is metabolized and about $5 \%$ via cy tochrome P-450 enzyme system (Slitt et al. 2005; Prescott 2005). Metabolism by cytochrome P- 450 produced $N$-acetyl- $p$-benzoquinone imine (NAPQI) which is a toxic metabolite to liver and kidney. At therapeutic doses, NAPQI is conjugated with reduced glutathione, an antioxidant compound, in the liver and NAPQI is excreted by the kidneys (da Silva Melo et al. 2006). At high doses, depletion of cellular GSH allows NAPQI to bind with cellular proteins and initiate lipid peroxidation which leads to renal and hepatic injury. The high antioxidant enzyme levels in AR-treated animals might play a significant role in the mechanism of the nephroprotective effect of $A$. racemosus root extract.

Oxidative stress and lipid peroxidation are early events related to free radicals generated in the metabolism of APAP. Free radical mediated chain reactions damage cell membrane, and MDA is the most important indicator for the degree of lipid peroxidation. Earlier studies have clearly demonstrated that acute APAP overdose increases the lipid peroxidation and suppresses the antioxidant defence mechanisms in renal tissues (Roy et al. 2013; Roy et al. 2014a). On oral administration of AR to Group IV animals, the levels of MDA decreased significantly in comparison to uremic animals (Group III). It was likely that the action of compounds present in this plant fraction is mainly related to its ability to scavenge lipid peroxidation-initiating agents.

The most important biochemical alteration in APAPinduced nephrotoxicity is inhibition of $\mathrm{Na}^{+} / \mathrm{K}^{+}$-ATPase. This enzyme regulates intracellular electrolytes and cell volume. Its damage may lead to enhancement of the electrolyte imbalance across the tubular cell membrane leading to the cellular lysis and tissue injury. Furthermore, nephrotoxicity and oxidative stress causes interference in ADH secretion. This may result in loss of large volumes of dilute urine and consequent rise in plasma osmolality and serum sodium concentration.

Elevations in blood urea, serum creatinine and acute tubular necrosis were often associated with drug-induced nephrotoxicity (Pradhan et al. 2013; Roy et al. 2015). The therapeutic components present in the root of A. racemosus, i.e. phytosterols, saponins, polyphenols, flavonoids and ascorbic acid (Visavadiya and Narsimhacharya 2005; Roy et al. 2014b) may be responsible for reduction of the APAP-induced toxicity.

Treatment with $A$. racemosus roots could have enhanced detoxification of APAP thereby maintaining the kidney architecture. The biochemical estimations were confirmed 
by the histological study of kidney tissues. Kidney sections of control groups (Fig. 1A, B) reveal normal kidney architecture with normal tubules and organized glomerulus. Kidney tissues of animals treated with APAP (Group III; Fig. 1C) showed loss of renal tubular architecture with dilated tubules and damages in glomeruli, and diffuse degenerative changes. In the renal tubules, massive cellular swelling and narrowing of lumen was evident. There were focal areas of necrosis with accumulation of protein casts in the tubular lumen. Rats treated with AR for 10 days (Group IV; Figure 1D) showed normal renal tubular architecture with organized glomeruli, very near to normal animals, there was only a very low degree of cellular swelling. The protective effects of this plant could have been due to presence of flavonoids and antioxidants (Roy et al. 2014b). These findings suggest the nephroprotective potentials of AR against acetaminophen-induced uraemia and oxidative stress.

A. racemosus roots contain phenols and flavonoids, chiefly responsible for antioxidant activity (Roy et al. 2014b). Also, the HPLC analysis of the ethanol fraction of AR showed that there was a major compound, which have similar retention time as quercetin, a flavonol from the flavonoid group of polyphenols. This compound may have comparable properties as quercetin, though further studies are necessary to identify this specific compound.

In conclusion, result suggests that the ethanol fraction of $A$. racemosus roots has a nephroprotective potential which reduces biochemical and histological damages associated with APAP toxicity. Further studies are required to find out the active principles and their possible mechanisms of action to aid the discovery of new therapeutic agents for the treatment of renal diseases.

\section{Acknowledgements}

The author thanks for financial help provided by Department of Science and Technology (DST), New Delhi in form of INSPIRE Fellowship to first author and also acknowledges to Dr. Pradip Ghosh, Director, Midnapore City College, Kuturiya, Paschim Medinipur for providing research facilities.

\section{References}

Beers RF, Sizer IW (1952) A spectrophotometric method for measuring the breakdown of hydrogen peroxide of catalase. J Biol Chem 195:133-140.

Burtis CA, Ashwood ER (1999) Tietz Textbook of Clinical Chemistry. 3rd ed, W. B. Saunders Co., Philadelphia. pp. 809-861.
Das K, Chakraborty PP, Ghosh D, Nandi DK (2010a) Protective effect of aqueous extract of Terminalia arjuna on dehydrating induced oxidative stress and uremia in male rat. Iran J Pharm Res 9:153-161.

Das K, Tulsian T, Samanta P, Nandi DK (2010b) Effect of extract of Withania sominifera on dehydration induced oxidative stress related uremia of male rat. Saudi J Kidney Dis Transpl 21:75-80.

Elkarib AO (2014) Impact of dehydro epiandrosterone in prevention of paracetamol induced nephrotoxicity in rats. Am Med J 5:16-27.

Fored CM, Ejerblad E, Lindbland P, Fryzek JP, Dickman PW, Signorello LB, Lipworth L, Elinder CG, Blot WJ, McLaughlin JK, Zack MM, Nyren O (2001) Acetaminophen, aspirin, and chronic renal failure. New Eng J Med 345:1801-1808.

Goyal RK, Singh J, Lal H (2003) Asparagus racemosus - An update. Indian J Med Sci 57:408-414.

Hardman JG, Limbird LE, Gilman AG (2001) Goodman and Gilman's The Pharmacological Basis of Therapeutics, 10th ed. Chapter 4. McGraw-Hill Medical Publishing Division, New York.

Linares V, Belles M, Albina ML, Sirvent JJ, Sanchez DJ, Domingo JL (2006). Assessment of the pro-oxidant activity of uranium in kidney and testis of rats. Toxicol Lett 167:152-161.

Mandal A, Mandal S, Roy S, Patra A, Pradhan S, Das K, Paul T, Mondal KC, Nandi DK (2013c) Assessment of efficacy of a potential probiotic strain and its antiuremic and antioxidative activities. e-SPEN J 8:155-163.

Mansour HH, Hafez HF, Fahmy NM (2006) Silymarin modulates cisplatin-induced oxidative stress and hepatotoxicity in rats. J Biochem Mol Biol 39:656-661.

Marklund S, Marklund G (1947) Involvement of superoxide anion radical in autotoxidation of pyrogallol and a convenient assay of superoxide dismutase. Eur J Biochem 47:469-474.

McLaughlin JK, Lipworth L, Chow WH, Blot WJ (1998) Analgesic use and chronic renal failure: a critical review of the epidemiologic literature. Kidney Int 54:679-686.

Mukherjee KL (2010) Medical Laboratory Technology. $2^{\text {nd }}$ ed. Chapter 4. New Delhi, Tata McGraw-Hill Education.

NIH (1985) NIH Guide for the Care and Use of Laboratory Animals. NIH Publication No.85-23. Bethesda MD: US Department of Health, Education and Welfare, National Institute of Health.

O'Grady JG (1997) Paracetamol-induced liver failure: prevention and management. J Hepatol 26:41-46.

Ohkawa H, Ohishi N, Yagi K (1976) Assay for lipid peroxidation in animal tissues by thiobarbituric acid reaction. Anal Biochem 95:351-358.

Olfert ED, Cross BM, McWilliam AA (1993) Guide to Care and Use of Experimental Animals, $2^{\text {nd }}$ ed. Chapter 2. 
Ottawa, CCAC.

Pradhan S, Mandal S, Roy S, Mandal A, Das K, Nandi DK (2013) Attenuation of uremia by orally feeding alphalipoic acid on acetaminophen induced uremic male rats. Saudi Pharm J 21:187-192.

Prescott L (2005) Oral or intravenous N-acetylcysteine for acetaminophen poisoning? Ann Emerg Med 45:409-413.

Roy S, Das K, Mandal S, Pradhan S, Patra A, Nandi DK (2013) Crude extract from root of Asparagus racemosus ameliorates acetaminophen induced uremic rats. Int J Pharm Sci Res 4: 3004-3012.

Roy S, Pradhan S, Das K, Mandal A, Mandal S, Patra A, Samanta A, Sinha B, Nandi DK (2015) Acetaminophen induced kidney failure in rats: a dose response study. J Biol Sci 15:187-193.

Roy S, Das K, Mandal S, Pradhan S, Patra A, Samanta A, Mandal A, Kar S, Nandi DK (2014a) Asparagus racemosus roots ameliorates acetaminophen induced hepatotoxicity in rats: an experimental, biochemical and histological study. Int J Recent Sci Res 5:1192-1197.

Roy S, Pradhan S, Mandal S, Das K, Patra A, Samanta A, Sinha B, Kar S, Nandi DK (2014b). Phytochemical analysis, antimicrobial activity and assessment of potential compounds by thin layer chromatography of ethanol fraction of Asparagus racemosus roots. Int J Pharm Pharm Sci 6:367-370. da Silva Melo DA, Saciura VC, Poloni JA, Oliveira CS, Filho JC, Padilha RZ, Reichel CL, Neto EJ, Oliveira RM, D'avila LC, Kessler A, de Oliveira JR (2006) Evaluation of renal enzymuria and cellular excretion as a marker of acute nephrotoxicity due to an overdose of acetaminophen in Wistar rats. Clin Chim Acta 373:88-91.

Slitt AML, Dominick PK, Roberts JC, Cohen SD (2005) Effects of ribose cysteine pretreatment on hepatic and renal acetaminophen metabolite formation and glutathione depletion. Basic Clin Pharmacol Toxicol 96:487-494.

Somani SM, Husain K, Whitworth C, Trammell GL, Malafa M, Rybak LP (2000) Dose-dependent protection by lipoic acid against cisplatin-induced nephrotoxicity in rats: antioxidant defense system. Pharmacol Toxicol 86: 234-241.

Sunderman FW (1959) Studies on the serum proteins. IV. The dye-binding of purified serum proteins separated by continuous-flow electrophoresis. Clin Chem 5:171-185.

Visavadiya NP, Narsimhacharya AV (2005). Hypolipidemic and antioxidant activities of Asparagus racemosus in hypercholesteromic rats. Indian J Pharmacol 37:376-380.

Youdin KA, Deans SG, Finlayson HJ (2002) The antioxidant properties of thyme (Thymus zygis L.) essential oil: an inhibitor of lipid peroxidation and a free radical scavenger. J Essen Oil Res 14: 210-215. 
